\title{
Batrachochytrium dendrobatidis in Germany: distribution, prevalences, and prediction of high risk areas
}

\author{
Torsten Ohst $^{1,2, *}$, Yvonne Gräser ${ }^{1}$, Jörg Plötner ${ }^{2}$
}

\begin{abstract}
${ }^{1}$ Institut für Mikrobiologie und Hygiene, Universitätsklinikum Berlin-Charité, Hindenburgdamm 27, 12203 Berlin, Germany
${ }^{2}$ Museum für Naturkunde, Leibniz Institut für Evolutions- und Biodiversitätsforschung, Invalidenstraße 43, 10115 Berlin, Germany
\end{abstract}

\begin{abstract}
In Germany, the pathogenic fungus Batrachochytrium dendrobatidis $(B d)$ was detected in 11 indigenous frog species, 4 newt species, and 1 salamander species in 64 out of the 181 locations (35\%) investigated. Among the 3450 samples collected between 2003 and 2011, 284 $(8.2 \%)$ were positive for $B d$ infections. The highest prevalences were observed in Alytes obstetricans (17.8\% of individuals, $20 \%$ of populations), followed by Ichthyosaura alpestris $(14.7 \%, 22.2 \%)$, Bombina variegata $(13.9 \%, 38.5 \%)$, and water frogs comprising 2 species, Pelophylax lessonae and $P$. ridibundus, and their hybrid form $P$. esculentus $(13.5 \%, 29.0 \%) . B d$ is widespread; areas of higher prevalence were detected in eastern, southeastern, western, and southwestern Germany. Our data indicate that drift fencing of amphibians is not a risk factor for the anthropogenic spread of $B d$. Although chytridiomycosis outbreaks have never been observed in Germany, it cannot be excluded that $B d$ infections affect the dynamics of local amphibian populations. Among the questions still to be answered is whether juveniles are more susceptible to $B d$ infections than adults. Further work, especially long-term observations including capture-mark-recapture studies, is required to clarify the impact $B d$ has on amphibians in Germany and Central Europe.
\end{abstract}

KEY WORDS: Batrachochytrium dendrobatidis · Chytridiomycosis · Germany · Distribution · Prevalence $\cdot$ Amphibian fencing

\section{INTRODUCTION}

Chytridiomycosis, a disease caused by the globally distributed fungus Batrachochytrium dendrobatidis $(B d)$, has been suggested to contribute significantly to the global decline of amphibians (e.g. Berger et al. 1998, Mendelson et al. 2006, Skerratt et al. 2007). Bd has been detected worldwide in more than 350 amphibian species (Fisher et al. 2009). Its impact on local populations, however, differs among species, areas, habitats, and seasons (Retallick et al. 2004, Daszak et al. 2005, Rachowicz et al. 2006, Schloegel et al. 2006, Murray et al. 2009, Phillott et al. 2013). The broad spatial distribution, high environmental tolerance, and wide range of host species suggest that $B d$ is a generalist pathogen (Ron 2005, Walker et al. 2010). The pathogenicity of $B d$ is presumably not only related to species-specific susceptibility and environmental conditions but also to the genetic traits of $B d$ strains (Fisher et al. 2009, Lam et al. 2010, Walker et al. 2010, Farrer et al. 2011, Rosenblum et al. 2013).

In Europe, chytridiomycosis seems to influence the dynamics of amphibian populations only locally, although $B d$ is probably widespread all over the continent (Garner et al. 2005, Rödder et al. 2010, Ohst et al. 2011, www.spatialepidemiology.net). High numbers of infected amphibians were detected on the Iberian Peninsula (Bosch \& Martínez-Solano 2006, Walker et al. 2010), in Switzerland (Garner et al. 
2005, Schmidt et al. 2009), Italy (Federici et al. 2008), and on Sardinia (Bovero et al. 2008, Bielby et al. 2009). Epidemiological data from the northern and eastern parts of Europe, however, are scarce.

In Germany, the first field record of $B d$ was obtained from the water frog hybrid Pelophylax esculentus, which was sampled in the state of Brandenburg, northeastern Germany (Mutschmann et al. 2000). Further records originated from $P$. esculentus, found in 2003 near Neuwied (Rhineland-Palatinate), Triturus alpestris (2001 and 2003) collected in southern Germany (Swabian Alb), and Salamandra salamandra (2001 and 2002) kept in an outdoor terrarium (Mutschmann 2007). Preliminary prevalence data obtained from all indigenous German amphibian species except $S$. atra indicate that $B d$ is widespread in Germany and is able to infect all species (Ohst et al. 2011). Chytridiomycosis outbreaks, however, have never been observed; therefore the role $B d$ plays in population declines in Germany, as in the whole of Central Europe, is not yet clear. We therefore as a first step estimated species-, population-, and locality-specific prevalence rates of $B d$ infections in Germany. Based on 3450 tissue samples from 181 localities, we aimed to explore the spatial patterns of $B d$ infections and detect areas of increased $B d$ prevalences in Germany as a basis for risk assessment and conservation management.

Despite the role $B d$ plays in the dynamics of amphibian populations, destruction, modification, and pollution of habitats, especially by agrochemicals (e.g. Brühl et al. 2013), are certainly the main factors that contributed to the dramatic population declines observed in recent decades in all European countries, including Germany (reviewed by Beebee \& Griffiths 2005, Laufer et al. 2007). For example, in the past 2 centuries, about 30 to $40 \%$ of water bodies were destroyed in the agricultural areas of the northeastern German states Mecklenburg-Western Pomerania and Brandenburg (Klafs et al. 1973, Wegener 1983, Greulich \& Schneeweiß 1996). In the western German Münsterland region, $82 \%$ of small water bodies, potential spawning sites for amphibians, disappeared within 19 yr (Stangier 1988).

Local road traffic also contributes to declines in amphibian populations. High car densities make roads effective isolation barriers for amphibians and other organisms; during their seasonal migrations many individuals are killed by cars when crossing roads or motorways (e.g. Fahrig et al. 1995). To diminish the negative impact of traffic, access to some roads is blocked by fences and amphibians are trapped in buckets before being carried safely across the road by conservationists, particularly in spring when amphibians migrate from hibernation places to spawning sites. This treatment potentially harbors the risk of increased infection rates, because many individuals touch each other and/or come into contact with contaminated equipment. We therefore attempted to estimate the effects that drift fencing may have on $B d$ prevalences by comparing amphibian samples collected at fences with samples from other localities collected randomly in their habitats.

\section{MATERIALS AND METHODS}

\section{Tissue sampling}

Tissue samples (Fig. 1, Table S1 in the Supplement at www.int-res.com/articles/suppl/d107p049_supp. pdf) were obtained between 2003 and 2011 using sterile cotton swabs (Sarsted \#80.625) by wiping the animal's ventral parts (belly, hind feet). The swabs were stored dry in tubes at room temperature until DNA extraction. Except Salamandra atra (which was not available in the study period), individuals of all indigenous taxa (mainly adults, several juveniles, 38 Alytes tadpoles) were collected by volunteers either with temporary amphibian fences (TAFs) using large pitfall traps (number of individuals, $\mathrm{n}_{\mathrm{i}}=1634$ ) or without drift fencing (designated as field samples, FS) in the aquatic and terrestrial habitats $\left(\mathrm{n}_{\mathrm{i}}=1816\right)$. Water frogs, comprising 2 species, Pelophylax ridibundus and $P$. lessonae, and their hybrid form $P$. esculentus, were pooled because of determination problems. We could not exclude, however, the possibility that water frog samples from western Germany contained allochthonous forms and/or hybrids between native and introduced lineages, especially samples from the Rhine and Ruhr valleys, where such forms are known to occur (reviewed by Plötner 2005, Ohst 2008). For localities at which samples were collected over 2 or more years (Table S1 in the Supplement), data were pooled before analysis.

\section{DNA preparation and $B d$ detection tests}

As most samples were taken in the field, swabs were heavily polluted by adhering soil and detritus that often cause strong or even complete inhibition of molecular assays and thus reduce the sensitivity of detection tests significantly (Kirshtein et al. 2007, Khot \& Fredricks 2009). We first tried rapid methods of DNA extraction using Prepman Ultra (Applied Bio- 


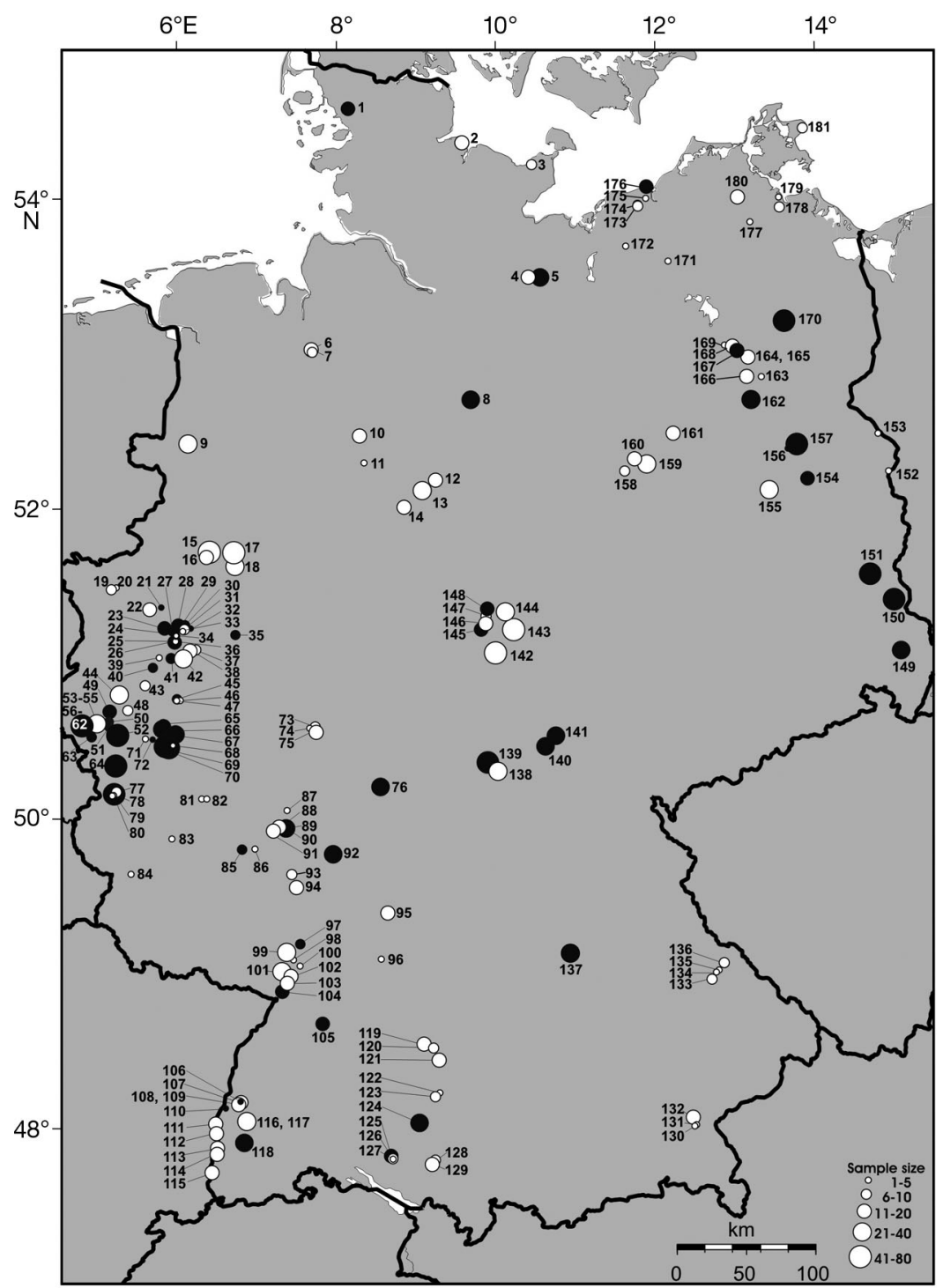

Fig. 1. Records of Batrachochytrium dendrobatidis infected amphibians in Germany between 2003 and 2011. Black circles: locations with infected amphibians; white circles: locations without infected amphibians. The size of the circles corresponds to the sample sizes. Locality numbers are specified in

Table S1 in the Supplement, which provides detailed locality information

was incubated for 2 min while mixing several times. After centrifugation at $1000 \times g$ for $1 \mathrm{~min}, 475 \mu \mathrm{l}$ of the supernatant was precipitated by addition of $380 \mu \mathrm{l}$ 2-propanol, incubated for $1 \mathrm{~h}$ at $-20^{\circ} \mathrm{C}$, and centrifuged at $21000 \times g$ for $12 \mathrm{~min}$. The supernatant was then discarded and the remaining DNA pellet was dried for $25 \mathrm{~min}$ at $60^{\circ} \mathrm{C}$. After dissolving the pellet in $30 \mu \mathrm{l}$ of buffer AE (Qiagen), the DNA was purified using the QIAquick PCR purification kit (Qiagen) according to the manufacturer's instructions. Finally, the DNA was eluted with $75 \mu \mathrm{l}$ of bidistilled water.

Even though a small amount of DNA was lost with each cleaning step, possibly lowering the number of $B d$ target copies below the detection limit in single samples, extensive cleaning was the best way to minimize the number of false negative samples. To verify the efficacy of the cleaning procedure, we performed 200 PCRs that contained a low concentration of an internal amplification control (IAC). The IAC was derived from a DNA plasmid and amplified with the same primers as the target gene. The IAC segment was amplified in all of these reactions, demonstrating the efficacy of our detection test.

To detect the DNA of $B d$, we modified the real-time TaqMan PCR assay described by Boyle et al. (2004), which amplifies a DNA fragment comprising parts of the internal transcribed spacer 1 (ITS-1) and the 5.8S ribosomal RNA gene. Unlike the original assay, we

systems) and DNeasy Blood and Tissue Kit (Qiagen). These methods do not, however, sufficiently suppress or remove inhibiting compounds, resulting in a low sensitivity for $B d$ detection. As a consequence, they can lead to a high number of false negative samples (Hyatt et al. 2007, Khot \& Fredricks 2009). To overcome this problem, we performed several steps to purify the extracted DNA.

Swab tips were incubated in $300 \mu$ of tissue lysis buffer ATL (Qiagen) for $15 \mathrm{~min}$ at $70^{\circ} \mathrm{C}$ and subsequently in $300 \mu \mathrm{l}$ lysis buffer AL (Qiagen) for $10 \mathrm{~min}$ at $95^{\circ} \mathrm{C}$. Thereafter, 1 to $2 \mathrm{mg}$ of polyvinylpolypyrrolidone (Sigma-Aldrich) were added and the solution used a TaqMan probe that was not conjugated with a minor groove binder protein but included locked nucleic acid bases to elevate the melting temperature (5'-6FAM CGA GTC+ G+AA+ C+A+A+AAT BBQ-3'). All quantitative $\mathrm{PCR}$ reactions were performed in a final volume of $20 \mu \mathrm{l}$, either on a LightCycler 2.0 or a LightCycler 480 (both Roche Applied Science). The reaction mixtures contained $0.25 \mu \mathrm{M}$ of each primer (ITS1-3 Chytr and 5.8S Chytr; Boyle et al. 2004),

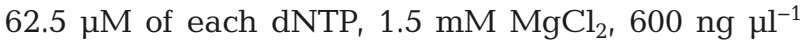
BSA (to reduce the impact of inhibiting compounds; Garland et al. (2010)), $2 \mu$ l of $10 \times$ reaction buffer (BD, Solis BioDyne), 1 unit Taq DNA polymerase (Ampli- 
Taq, ABI), and $1 \mu \mathrm{l}$ DNA. The cycling profile consisted of an initial denaturation step at $96^{\circ} \mathrm{C}$ for $5 \mathrm{~min}$, followed by 50 cycles of $10 \mathrm{~s}$ at $96^{\circ} \mathrm{C}$ and $1 \mathrm{~min}$ at $60^{\circ} \mathrm{C}$.

In each run we included appropriate negative and positive controls. To quantify infection intensity, standard curves were constructed from control reactions containing 11, 110, 1100, and 11000 copies of the target DNA fragment. Samples were considered as positive when threshold cycle values (PCR cycle at point of detection) were equal to or exceeded the level for 11 copies of the target fragment, which corresponds to about 0.1 zoospore genomic equivalents (Kirshtein et al. 2007), a common standard that can still be reliably amplified (e.g. Boyle et al. 2004, Skerratt et al. 2011). Samples found to be positive in the first round were tested a second time to confirm the result and reduce the number of false positive counts probably caused by contamination in the laboratory (Skerratt et al. 2011).

\section{Statistical analyses}

\section{Species- and locality-specific prevalence rates}

Prevalence data were analyzed using the program Statgraphics Centurion Version 15.2.14 (Statpoint Technologies). Species-specific prevalence rates were calculated on the basis of individuals $\left(P_{\text {Ind }}\right)$ and populations $\left(P_{\text {Pop }}\right)$ by dividing the number of infected individuals $\left(\mathrm{n}_{\mathrm{i}+}\right)$ or populations $\left(\mathrm{n}_{\mathrm{p}+}\right)$ by the number of individuals $\left(\mathrm{n}_{\mathrm{i}}\right)$ or populations $\left(\mathrm{n}_{\mathrm{p}}\right)$ investigated. Mean prevalences $\left(P_{\text {mean }}\right)$ and standard deviations were calculated for each species on the basis of population-specific prevalence values using standard formulas. $95 \%$ confidence intervals for $P_{\text {mean }}$ were computed using the bootstrap method with 1000 replicates as implemented in Statgraphics.

Additionally, we calculated locality-specific prevalence rates $\left(P_{\text {Loc }}\right)$ by dividing the number of amphibians infected $\left(\mathrm{n}_{\mathrm{a}+}\right)$ by the number of amphibians investigated $\left(\mathrm{n}_{\mathrm{a}}\right)$. For 3 localities $(124,149,150$; Fig. 1, Table S1 in the Supplement) prevalences obtained in May of 2 successive years $(2009,2010)$ were compared and linked to the average winter temperature before the samples were collected.

As prevalence data are characterized by an inflation of zero counts and thus are not normally distributed, a Freeman-Tukey transformation (Cressie 1992) was used to normalize the data and to reduce their variance. Prevalence rates were transformed into $Z$-values according to the formula

$$
Z=\sqrt{\frac{\mathrm{n}_{+}}{\mathrm{n}}}+\sqrt{\frac{\mathrm{n}_{+}+1}{\mathrm{n}}}
$$

where $n_{+}$is the number of infected individuals or populations and $\mathrm{n}$ is the total number of individuals or populations investigated. If this transformation failed to result in a normal distribution, nonparametric statistics were used; for comparisons of independent samples, the non-parametric MannWhitney-Wilcoxon (MWW) test was used. A $\chi^{2}$ test was performed to determine whether there were significant differences among the observed prevalences $(P)$ in the amphibian species investigated, followed by an analysis of means (ANOM) to determine which proportions were significantly different from the overall average $(\bar{P})$.

\section{Scanning for local clusters of $B d$ infections}

To screen for local clusters of $B d$ infections, Kulldorff's spatial scan statistics (Kulldorff \& Nagarwalla 1995, Kulldorff 1997) was applied as implemented in ClusterSeer 2.51 (BioMedware). This method finds spatial clusters by detecting excesses of cases in a given region under the assumption that cases are generated by an inhomogeneous Poisson point process with an intensity $\mu$, proportional to the population at risk. In the scan process, a circular window is moved systematically through the study area, starting at the centroid of each location in the dataset (Kulldorff 1999). The window expands to include the nearest region centroids, but its maximum size does not exceed $50 \%$ of the total population-at-risk size for the study period. A maximum likelihood ratio test was applied to evaluate whether the data pattern was a realisation of an inhomogeneous Poisson point process $\left(H_{0}\right)$, or the number of cases exceeded that predicted under $H_{0}$ in some locations in the study area $\left(H_{a}\right)$. The scan statistic was the maximum likelihood ratio over all possible window sizes; its p-value was obtained through 1000 Monte Carlo randomizations based on a multinomial randomization.

\section{RESULTS}

\section{Species- and locality-specific prevalences}

$B d$ was detected in $8.23 \%$ of the individuals and $35.4 \%$ of the amphibian communities (localities) tested (Fig. 1, Table 1). The copy number of $B d$-target gene segments determined in positive samples ranged 
between 11 (detection limit) and 60600 copies per $\mu \mathrm{l}$, which is equivalent to 0.065 and 359 zoospores per $\mu \mathrm{l}$ and swab (Kirshtein et al. 2007). The highest prevalences calculated on the basis of infected individuals $\left(P_{\text {Ind }}\right)$ were observed in Alytes obstetricans $(17.8 \%)$, Ichthyosaura alpestris $(14.7 \%)$, Bombina variegata $(13.9 \%)$, and water frogs (Pelophylax spp., $13.5 \%$ ). Based on a lower decision limit (LDL) of 0.03 and an upper decision limit (UDL) of 0.14, proportions of infected individuals were significantly higher in $A$. obstetricans and Pelophylax spp. than the mean value of $\bar{P}=0.082$, but significantly lower in Bufo bufo (ANOM: $\chi^{2}=103.85, \mathrm{df}=16, \mathrm{p}<0.001$ ).

Values of prevalences based on infected populations $\left(P_{\text {Pop }}\right)$ ranged between $11.8 \%$ (Rana arvalis) and $42.9 \%$ (Bufo calamita) with a mean value of $21.4 \%$ (Table 1). There was no significant departure from the mean (LDL $=0.0, \mathrm{UDL}=0.46$ ) for either of the species-specific $P_{\text {Pop }}$ values $\left(\chi^{2}=15.64, \mathrm{df}=16\right.$, $\mathrm{p}=0.48$ )

We found a significant moderate positive correlation $\left(\mathrm{R}^{2}=49.3 \%, F=14.58, \mathrm{p}=0.002\right)$ between $Z_{\text {Ind }}$ and $Z_{\text {Pop }}$ (Fig. 2). Points outside the $95 \%$ confidence intervals were attributed to species with high $P_{\text {Ind }}$ values (Alytes obstetricans, Ichthyosaura alpestris, Pelophylax spp.), and species with low $P_{\text {Ind }}$ but comparatively high $P_{\text {Pop }}$ values (Pelobates fuscus, Bufo calamita) probably caused by stochastic effects linked to the relatively small numbers of populations investigated (9 and 7 , respectively). Populationspecific mean prevalences $\left(P_{\text {mean }} \pm \mathrm{SD}\right)$ varied between $1.4 \pm 4.10 \%$ (Rana arvalis) and $28.9 \pm 48.59 \%$ (B. calamita).

\section{Effects of sample sizes on estimates of prevalence rates}

The probability of detecting infected individuals at a location was significantly influenced by both the sample size $\left(\mathrm{n}_{\mathrm{i}}\right)$ and the number of species $\left(\mathrm{n}_{\mathrm{s}}\right)$ in the sample. Samples from locations with $B d$ infections $(\mathrm{n}=64)$ were significantly larger (arithmetic mean $[ \pm \mathrm{SD}], \bar{X}=30.7 \pm 42.23$; median, $\widetilde{X}=19.5$ ) than samples from locations without infected individuals $(\mathrm{n}=117, \bar{X}=12.7 \pm 12.27, \widetilde{X}=10.0$; MWW test: $W=5173.0, \mathrm{p}<0.001, \alpha=0.05$ ). The number of species was significantly higher in samples from locations where at least one species tested positive for $B d$ infections (MWW test: $W=4481.0, \mathrm{p}=0.02$, $\alpha=0.05)$, expressed by both the arithmetic mean $(\bar{X}=2.6 \pm 2.0)$ and median $(\widetilde{X}=2.0)$; the corresponding values of negative samples were $\bar{X}=1.90 \pm 1.26$ and $\widetilde{X}=1.0$. Our opportunistic sample design may

Table 1. Batrachochytrium dendrobatidis infections in German amphibians recorded between 2003 and $2011 . \mathrm{n}_{\mathrm{i}}, \mathrm{n}_{\mathrm{p}}$ : number of individuals (i) or populations $(\mathrm{p})_{i} \mathrm{n}_{\mathrm{i}+}, \mathrm{n}_{\mathrm{p}+}$ : number of individuals or populations infected ${ }_{i} P_{\text {Ind }}, P_{\text {Pop }}$ : percentage of individuals or populations infected; Min-Max: minimal-maximal population specific prevalence rate; $P_{\text {mean }} \pm$ SD: arithmetic mean of prevalence rates calculated for single populations \pm standard deviation; $\mathrm{BI}_{\text {mean }}: 95 \%$ confidence intervals for the arithmetic mean calculated with the bootstrap method (1000 replicates); $\bar{P}$ : arithmetic mean of $P_{\text {Ind }}$ and $P_{\text {Pop }}$

\begin{tabular}{|c|c|c|c|c|c|c|c|c|c|}
\hline \multirow[t]{2}{*}{ Species } & \multicolumn{3}{|c|}{ - Individuals } & \multicolumn{3}{|c|}{ — Populations _ـ } & \multirow{2}{*}{$\begin{array}{c}\text { Min-Max } \\
(\%)\end{array}$} & \multirow{2}{*}{$\begin{array}{c}P_{\text {mean }} \pm \mathrm{SD} \\
(\%)\end{array}$} & \multirow{2}{*}{$\begin{array}{c}\mathrm{BI}_{\text {mean }} \\
(\%)\end{array}$} \\
\hline & $\mathrm{n}_{\mathrm{i}}$ & $\mathrm{n}_{\mathrm{i}+}$ & $P_{\text {Ind }}(\%)$ & $\mathrm{n}_{\mathrm{p}}$ & $\mathrm{n}_{\mathrm{p}+}$ & $P_{\text {Pop }}(\%)$ & & & \\
\hline Salamandra salamandra & 16 & 1 & 6.2 & 3 & 1 & 33.3 & $0.0-10.0$ & $3.3 \pm 5.77$ & $0.0-10.0$ \\
\hline Ichthyosaura alpestris & 150 & 22 & 14.7 & 36 & 8 & 22.2 & $0.0-100$ & $11.6 \pm 28.90$ & $3.5-22.0$ \\
\hline Lissotriton helveticus & 37 & 3 & 8.1 & 10 & 3 & 30.0 & $0.0-33.3$ & $6.4 \pm 11.45$ & $0.0-13.3$ \\
\hline Lissotriton vulgaris & 137 & 4 & 2.9 & 31 & 4 & 12.9 & $0.0-25.0$ & $2.1 \pm 6.04$ & $0.3-4.6$ \\
\hline Triturus cristatus & 103 & 7 & 6.8 & 19 & 5 & 26.3 & $0.0-100$ & $13.3 \pm 31.56$ & $1.2-29.1$ \\
\hline Alytes obstetricans & 146 & 26 & 17.8 & 10 & 2 & 20.0 & $0.0-71.4$ & $12.7 \pm 2.70$ & $0.0-30.9$ \\
\hline Bombina bombina & 106 & 8 & 7.6 & 10 & 2 & 20.0 & $0.0-33.3$ & $5.5 \pm 11.95$ & $0.0-14.3$ \\
\hline Bombina variegata & 108 & 15 & 13.9 & 13 & 5 & 38.5 & $0.0-57.1$ & $11.2 \pm 17.92$ & $3.2-21.2$ \\
\hline Bufo bufo & 1014 & 56 & 5.5 & 87 & 16 & 18.4 & $0.0-50.0$ & $4.3 \pm 11.52$ & $2.0-7.1$ \\
\hline Bufo calamita & 195 & 6 & 3.1 & 7 & 3 & 42.9 & $0.0-100$ & $28.9 \pm 48.59$ & $0.3-71.4$ \\
\hline Bufo viridis & 56 & 4 & 7.1 & 6 & 2 & 33.3 & $0.0-12.5$ & $3.8 \pm 5.86$ & $0.0-7.9$ \\
\hline Hyla arborea & 116 & 4 & 3.4 & 8 & 1 & 12.5 & $0.0-23.5$ & $2.9 \pm 8.32$ & $0.0-8.8$ \\
\hline Pelebates fuscus & 112 & 3 & 2.7 & 9 & 3 & 33.3 & $0.0-100$ & $12.2 \pm 33.04$ & $0.0-34.6$ \\
\hline Pelophylax spp. & 869 & 117 & 13.5 & 69 & 20 & 29.0 & $0.0-100$ & $9.3 \pm 20.62$ & $5.1-14.6$ \\
\hline Rana arvalis & 93 & 2 & 2.2 & 17 & 2 & 11.8 & $0.0-14.3$ & $1.4 \pm 4.10$ & $0.0-3.4$ \\
\hline Rana dalmatina & 16 & 0 & 0 & 8 & 0 & 0 & - & 0 & - \\
\hline Rana temporaria & 176 & 6 & 3.4 & 44 & 6 & 13.6 & $0.0-50.0$ & $5.0 \pm 13.80$ & $1.5-9.4$ \\
\hline Sum & 3450 & 284 & & 387 & 83 & & & & \\
\hline$\overline{\boldsymbol{P}}(\%)$ & & & 8.23 & & & 21.4 & & & \\
\hline
\end{tabular}




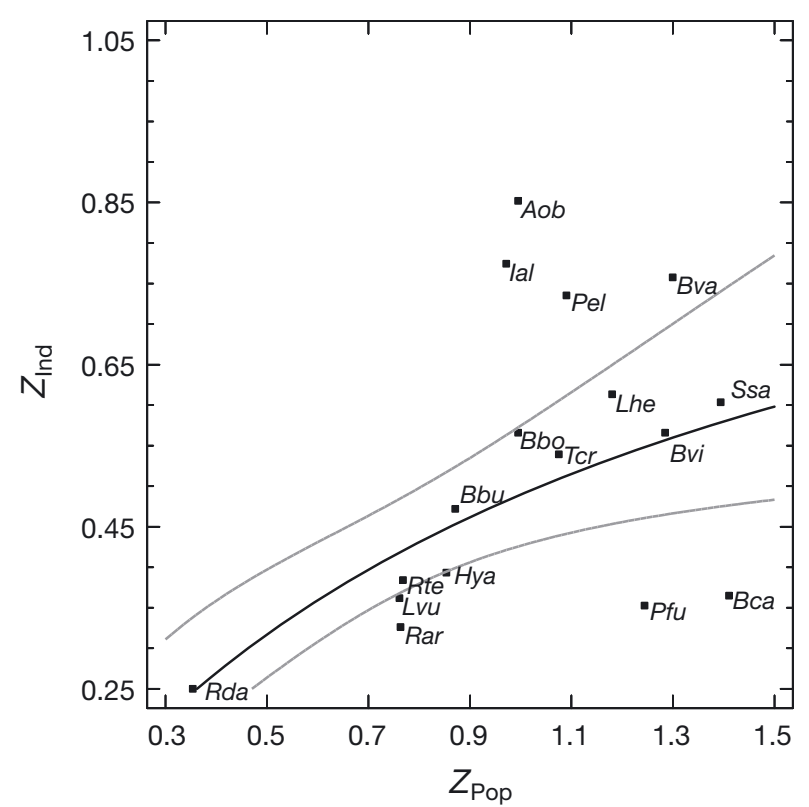

Fig. 2. Correlation between individual-based $\left(Z_{\text {Ind }}\right)$ and population-based $\left(Z_{\mathrm{Pop}}\right)$ species-specific Freeman-Tukey transformed prevalences. A high species-specific susceptibility can be characterized by high numbers of both infected individuals and populations. Equation of the fitted model: $Z_{\text {Ind }}=$ $1 /\left(0.93+1.11 / Z_{\text {Pop }}\right)$. Black line: regression line; grey lines: $95 \%$ confidence limits. Points outside the $95 \%$ confidence limits are attributed to species with comparatively high numbers of infected individuals (Aob, Ial, Pel) or low numbers of infected individuals but higher numbers of infected populations $(P f u, B C a)$. Species abbreviations in alphabetical order: Aob: Alytes obstetricans; Bbu: Bufo bufo; Bbo: Bombina bombina; Bca: Bufo calamita; Bva: Bombina variegata; Bvi: Bufo viridis; Har: Hyla arborea; Ial: Ichthyosaura alpestris; Lhe: Lissotriton helveticus; Lvu: Lissotriton vulgaris; Pel: Pelophylax spp.; Pfu: Pelebates fuscus; Rar: Rana arvalis; Rda: Rana dalmatina; Rte: Rana temporaria; Ssa: Salamandra salamandra; Tcr: Triturus cristatus

thus cause a bias of false negative results, so higher prevalence rates than those estimated from our data can be expected. If only localities with a minimum of 30 individuals are considered, the prevalence rate over all individuals and species increases from 8.23 to $9.04 \%$. Moreover, $B d$ was recorded in 16 out of 26 amphibian communities with sample sizes $\geq 30$, i.e. in $61.5 \%$ of the locations, which suggests that the actual value of $B d$ positive locations is much higher than $35 \%$.

\section{Effects of the sampling method and sampling time on estimates of prevalence rates}

To explore in another way whether the sampling method influenced the results, and especially to esti- mate whether TAFs pose an increased risk of infection, prevalences of samples obtained at TAFs were compared with prevalences calculated for samples from other localities collected randomly in the field (FS). Although both $n_{i}$ and $n_{s}$ per sampling site were significantly higher in the TAF subsample, the prevalence rate was lower than in the FS subsample (Table 2). This finding indicates that, beside sample size parameters, other factors linked with the sampling method may also influence prevalence estimates.

As one possible factor, species with comparatively higher or lower $B d$ prevalences may have biased the prevalence estimates in our subsamples. Among the 22 Alytes obstetricans individuals collected at a TAF no $B d$ positive individual was found, and for Pelophylax spp. the prevalence in individuals collected at TAFs was half the value for the FS subsample (14\%), although a contingency table $(4 \times 4)$ revealed no influence of the sampling method on the number of infected and non-infected individuals $\left(\chi^{2}\right.$ Yates $=1.59$, $\mathrm{df}=1, \mathrm{p}=0.207$ ). Moreover, $Z$ values estimated for Pelophylax populations correlated significantly with locality-specific $Z$ values $\left(\mathrm{R}^{2}=58.4 \%, \mathrm{r}=0.76\right.$, $\mathrm{p}<0.001)$. We therefore omitted both the Alytes and Pelophylax data from analysis, re-estimated $P_{\text {Loc }}$ and $Z_{\text {Loc }}$ for all localities, and compared the prevalence values of the 2 subsamples. The $Z$ values calculated for TAF and FS for these re-estimated prevalences were as different as they were for the complete data set (Table 2).

Samples collected in May 2009 at localities 124, 149, and 150 exhibited higher prevalences (1.4 to $3.8 \%, \bar{X}=24.1 \pm 12.03 \%, \widetilde{X}=20.4 \%$ ) than samples collected in May 2010 (0.0 to $1.5 \%, \bar{X}=4.9 \pm 8.55 \%$, $\widetilde{X}=0 \%$ ) at the same places. The difference of means, however, was not significant.

\section{Geospatial patterns of prevalences}

Kulldorff's scan statistics revealed 3 likely clusters. The first, with an average prevalence of $P_{\text {mean }}=25.1 \%$, a $\log$ likelihood ratio (LLR) of 30.94, and an upper-tail p-value $<0.001$, comprises 5 localities (150 to 154) situated in eastern Germany (Brandenburg state), the second cluster $\left(P_{\text {mean }}=41.8 \%\right.$, LLR $=23.9, \mathrm{p}<0.001)$ incorporates 3 sites $(29,30,32)$ in western Germany (North Rhine-Westphalia), and the third cluster $\left(P_{\text {mean }}=23.5 \%, \mathrm{LLR}=11.3, \mathrm{p}<0.001\right)$ includes 3 sites in Thuringia $(138,140,141)$ and 2 sites in Bavaria $(133,137)$ (Fig. 1, Table S1 in the Supplement). 
Table 2. Sample sizes $(\mathrm{n})$, number of individuals $\left(\mathrm{n}_{\mathrm{i}}\right)$, number of species $\left(\mathrm{n}_{\mathrm{s}}\right)$, and prevalence parameters $\left(P_{\mathrm{Loc}}, Z_{\mathrm{Loc}}\right)$ of amphibian samples collected at temporary amphibian fences (TAFs) and in other locations without drift fencing (FS). For each parameter the observed range (first line), mean \pm standard deviation (second line), and median (third line) are specified. Parameter differences were tested using the non-parametric 2-tailed Mann-Whitney-Wilcoxon (MWW) test $(\alpha=0.05)$. Bold p-values indicate significant differences $(\mathrm{p}<0.05) .{ }^{*}$ : omitting Alytes and Pelophylax spp.

\begin{tabular}{|c|c|c|c|c|c|c|}
\hline Parameter & TAF & FS & MWW & $\mathrm{TAF}^{*}$ & $\mathrm{FS}^{*}$ & $\mathrm{MWW}^{*}$ \\
\hline $\mathrm{n}$ & 77 & 104 & & 77 & 60 & \\
\hline $\mathrm{n}_{\mathrm{i}}$ & $\begin{array}{c}1-228 \\
21.22 \pm 28.071 \\
15\end{array}$ & $\begin{array}{c}1-186 \\
17.46 \pm 28.323 \\
9\end{array}$ & $\begin{array}{c}W=5164.5 \\
\mathbf{p}<\mathbf{0 . 0 0 1}\end{array}$ & - & - & - \\
\hline $\mathrm{n}_{\mathrm{s}}$ & $\begin{array}{c}1-10 \\
2.97 \pm 1.878 \\
3.0\end{array}$ & $\begin{array}{c}1-6 \\
1.52 \pm 0.975 \\
1.0\end{array}$ & $\begin{aligned} W & =6033.0 \\
\mathbf{p} & <\mathbf{0 . 0 0 1}\end{aligned}$ & - & - & - \\
\hline$P_{\text {Loc }}(\%)$ & $\begin{array}{c}0.0-50.0 \\
6.04 \pm 12.400 \\
0.0\end{array}$ & $\begin{array}{c}0.0-100 \\
10.38 \pm 21.157 \\
0.0\end{array}$ & $\begin{array}{l}- \\
-\end{array}$ & $\begin{array}{c}0.0-66.7 \\
6.05 \pm 13.173 \\
0.0\end{array}$ & $\begin{array}{c}0.0-100 \\
9.30 \pm 20.943 \\
0.0\end{array}$ & $\begin{array}{l}- \\
-\end{array}$ \\
\hline$Z_{\text {Loc }}$ & $\begin{array}{c}0.14-1.71 \\
0.50 \pm 0.354 \\
0.35\end{array}$ & $\begin{array}{c}0.13-2.41 \\
0.70 \pm 0.476 \\
0.58\end{array}$ & $\begin{aligned} W & =2989.0 \\
\mathbf{p} & =\mathbf{0 . 0 0 4}\end{aligned}$ & $\begin{array}{c}0.15-1.82 \\
0.51 \pm 0.363 \\
0.35\end{array}$ & $\begin{array}{c}0.13-2.41 \\
0.69 \pm 0.486 \\
0.58\end{array}$ & $\begin{aligned} W & =2856.5 \\
\mathbf{p} & =\mathbf{0 . 0 1 8}\end{aligned}$ \\
\hline
\end{tabular}

\section{DISCUSSION}

Our data clearly indicate that (1) $B d$ is widely distributed in Germany and (2) has the potential to infect all indigenous amphibian species. Because of missing data, however, we do not know whether Salamandra atra is susceptible to $B d$ infections. Schmidt et al. (2009) did not detect infected S. atra, probably because their sample, like ours, was small (20 individuals); Lötters et al. (2012), however, did not find infected $S$. atra in 310 samples either. A small sample (16 individuals from 8 populations) may also be the reason that we did not detect $B d$ in Rana dalmatina, a species known to be susceptible to $B d$ infections (Schmidt et al. 2011, Sztatecsny \& Hödl 2011).

Five of the 21 amphibian species living in Germany are classified as 'vulnerable' and 2 as 'endangered'; on a regional scale (federal states) all species are more or less threatened (www.amphibienschutz.de). Consistency between the threat status and $B d$ prevalence, however, is only seen in Bombina variegata (endangered or critically endangered) and Alytes obstetricans (vulnerable or regionally extinct). Our prevalence estimates for Alytes are consistent with the high susceptibility of midwife toads to $B d$ infections (e.g. Bosch et al. 2001, Garner et al. 2005, Tobler \& Schmidt 2010). In one area (environs of Bochum, locality 30) from which we obtained only Alytes tadpoles, 21 of 38 individuals (55.3\%) were $B d$ positive. During tadpole development, the infection rate increased to $98 \%$ (authors' unpubl. data). Without considering tadpoles, however, the species-specific prevalence estimate of Alytes amounted to only
$4.6 \%$. This result emphasizes the need for distinguishing between larvae and tadpoles, juveniles, subadults, and adults when estimating $B d$ prevalences (e.g. Skerratt et al. 2008, Piovia-Scott et al. 2011). High infection rates were also observed in water frogs, which parallels observations in different parts of Europe and Asia (e.g. Sztatecsny \& Hödl 2011, J. Plötner et al. unpubl. data).

Compared with $B d$ prevalences estimated for other regions in Europe, for example, Austria $(20 \%$; Sztatecsny \& Glaser 2011), the overall prevalence rate of $8.23 \%$ estimated for German amphibians is judged to be moderate, although it seems possible that $B d$ occurs in up to $60 \%$ of the populations. An opportunistic sample design, small sample sizes, and poor or missing data (gaps in the grid), especially in the northwestern and southeastern parts of Germany, may obscure the real situation. Moreover, many other factors may bias prevalence estimation, for example, the number and spectrum of species in a sample, the season when samples were collected (Skerratt et al. 2008, 2010, Voordouw et al. 2010, Kinney et al. 2011, Piovia-Scott et al. 2011, T. Ohst et al. unpubl.), and, as mentioned above, the life stage of the individuals tested. As larvae and juvenile amphibians (especially recently metamorphosed individuals) seem more susceptible than adults to $B d$ infections (Waldman et al. 2001, Lamirande \& Nichols 2002, Bosch et al. 2007, Walker et al. 2010, PioviaScott et al. 2011, authors' unpubl data), the overall prevalence estimated in this study may be representative only for the adult population because the majority of individuals tested were adults. 
Since the initial detection of $B d$ in Europe, there has been increasing concern among herpetologists and conservationists whether drift fencing of amphibians enhances the risk of $B d$ infection because many individuals of different species converge; often several dozen specimens are collected in a single trap. Although our data do not exclude the possibility of increased infection rates at drift fences, they also do not provide arguments against the use of TAFs or of permanent amphibian guidance installations. Contrary to the expectations derived from the sample structure, the overall prevalence estimated for amphibians collected at TAFs was lower than in the field subsample (FS), even though both the number of individuals and species per sample site were higher in the TAF subsample. There are 3 equally parsimonious scenarios that may contribute, separately or in concert, to this result: (1) a decrease of $B d$ infections with decreasing temperatures in winter; (2) an increased mortality of infected individuals during hibernation; and (3) rapid evolution of resistance to $B d$ infections in populations confronted with TAFs for several years.

At present, we do not know the causes for the lower prevalence rate estimated for our TAF subsample. There is evidence, however, that the development of $B d$ is temperature dependent (scenario 1). The optimum temperature for growth of $B d$ in vitro is $23^{\circ} \mathrm{C}$; temperatures above $29^{\circ} \mathrm{C}$ lead to death of the fungus (Berger et al. 2004). Temperatures below $6^{\circ} \mathrm{C}$, which are common during hibernation, suppress the development of Bd (Bradley et al. 2002, Woodhams et al. 2003), and may lead to a decreased fungal load and thus lower prevalence rates in spring after hibernation when amphibians arrive at TAFs. Indirect evidence for this hypothesis comes from the comparison of prevalences estimated for the same 3 localities $(124,149,150)$ both in May 2009 and 2010. The lower values revealed for 2010 (4.9\%) compared with 2009 $(24.1 \%)$ correspond to the fact that the 2009-2010 winter was longer and colder (mean temperatures December to February: $\sim 1.8^{\circ} \mathrm{C}$, climate station Cottbus, state Brandenburg) than the 2008-2009 winter with a mean value of $\sim 0.1^{\circ} \mathrm{C}$. With increasing temperatures in late spring and early summer, $B d$ is expected to grow again, resulting in higher prevalences at the end of the breeding season. In midsummer, unfavourable ecological conditions for Bd (Berger et al. 2004, Kriger \& Hero 2007, Murray et al. 2009) may result in decreasing pathogenic loads, especially in periods with high temperatures (Berger 2001), low humidity, and increased UV radiation (Ortiz-Santaliestra et al. 2011). Even in semi-aquatic amphibians, such as water frogs, the fungal load can decrease below the detection threshold during summer (T. Ohst et al. unpubl. results). Seasonal changes in $B d$ prevalence and chytridiomycosis-associated mortality have been observed, for example, in the Australian frog species Litoria pearsoniana and L. rheocola (Murray et al. 2009, Phillott et al. 2013). Although the 2 populations of $L$. rheocola investigated have been faced with $B d$ for almost 2 decades, chytridiomycosis continues to have substantial seasonally fluctuating population-level effects on amphibian survival (Phillott et al. 2013).

Temperature influences not only the growth of $B d$, but also the immune system of amphibians (reviewed by Carey et al. 1999, Raffel et al. 2006). In ectotherms, decreasing temperatures are correlated with a decreased immune reactivity. The complexity of ecologically mediated host-germ interactions is thought to be linked with seasonal and regional differences in the outbreaks of infectious diseases, including chytridiomycosis (Berger et al. 2004). In this context, global warming may, in future, increase the pathogenicity of $B d$ in so far unaffected regions; concrete predictions are, however, difficult to make.

Last but not least, methodical errors could also affect prevalence estimates. For example, differences in the demographic structures of samples and/or a selective collection of infected individuals in the field caused by behavioral changes resulting from infection.

\section{CONCLUSIONS}

Our results indicate that $B d$ is widespread across a broad host range in Germany. No chytridiomycosisdriven losses in amphibians were reported during the past decade and the highest zoospore loads estimated in this study were far below the threshold of 10000 zoospores per swab that was determined for populations with epizootic outbreaks of chytridiomycosis (Vredenburg et al. 2010, Kinney et al. 2011). We cannot exclude, however, that $B d$ influences the dynamics of amphibian populations via an increased mortality in juveniles, especially at the end of metamorphosis or shortly after (Tobler \& Schmidt 2010). Therefore, further research, including long-term monitoring (Murray et al. 2009, Phillott et al. 2013) in selected areas and systematic sampling along transects, is urgently needed to obtain a basis for an objective risk assessment for indigenous amphibians. Among the questions that remain unanswered, the influence of environmental factors, such as agro- 
chemicals, on pathogen-host interactions is of special interest (Plötner \& Matschke 2012). Finally, data on the genetic variability of $B d$ strains associated with strain-specific virulence (Farrer et al. 2011, Rosenblum et al. 2013) are of great importance not only for Germany, but for Central Europe in general.

Acknowledgements. We thank T. Uzzell (Philadelphia), L. Skerratt (Townsville), and 2 anonymous reviewers for constructive and critical comments on the manuscript. We are grateful to all the people who kindly provided tissue samples. Grateful thanks are given to R. Schreiber (Museum für Naturkunde, Berlin), S. Bartels, and K. Otte for technical assistance. This research was supported by the Deutsche Forschungsgemeinschaft (grants PL 213/6-1 and GR 1467/ 11-1).

\section{LITERATURE CITED}

Beebee TJC, Griffiths RA (2005) The amphibian decline crisis: A watershed for conservation biology? Biol Conserv 125:271-285

Berger L (2001) Diseases in Australian frogs. PhD dissertation, James Cook University, Townsville

> Berger L, Speare R, Daszak P, Green DE and others (1998) Chytridiomycosis causes amphibian mortality associated with population declines in the rain forests of Australia and Central America. Proc Natl Acad Sci USA 95: 9031-9036

Berger L, Speare R, Hines HB, Marantelli G and others (2004) Effect of season and temperature on mortality in amphibians due to chytridiomycosis. Vet J 82:31-36

- Bielby J, Bovero S, Sotgiu G, Tessa G and others (2009) Fatal chytridiomycosis in the Tyrrhenian painted frog. EcoHealth 6:27-32

Bosch J, Martínez-Solano I (2006) Chytrid fungus infection related to unusual mortalities of Salamandra salamandra and Bufo bufo in the Peñalara Natural Park, Spain. Oryx 40:84-89

Bosch J, Martínez-Solano I, García-París M (2001) Evidence of a chytrid fungus infection involved in the decline of the common midwife toad (Alytes obstetricans) in protected areas of central Spain. Biol Conserv 97:331-337

Bosch J, Carrascal LM, Duran L, Walker S, Fisher MC (2007) Climate change and outbreaks of amphibian chytridiomycosis in a montane area of Central Spain; Is there a link? Proc R Soc Lond B Biol Sci 274:253-260

> Bovero S, Sotgiu G, Angelini C, Doglio S, Gazzaniga E, Cunningham AA, Garner TWJ (2008) Detection of chytridiomycosis caused by Batrachochytrium dendrobatidis in the endangered Sardinian newt (Euproctus platycephalus) in southern Sardinia, Italy. J Wildl Dis 44:712-715

> Boyle DG, Boyle DB, Olsen V, Morgan JAT, Hyatt AD (2004) Rapid quantitative detection of chytridiomycosis (Batrachochytrium dendrobatidis) in amphibian samples using real-time Taqman PCR assay. Dis Aquat Org 60:141-148 PubMed

- Bradley GA, Rosen PC, Sredl MJ, Jones TR, Longcore JE (2002) Chytridiomycosis in native Arizona frogs. J Wildl Dis 38:206-212

Brühl CA, Schmidt T, Pieper S, Alscher A (2013) Terrestrial pesticide exposure of amphibians: An underestimated cause of global decline? Sci Rep 3:1135

Carey C, Cohen N, Rollins-Smith L (1999) Amphibian declines: an immunological perspective. Dev Comp Immunol 23:459-472

- Cressie N (1992) Statistics for spatial data. Terra Nova 4: 613-617

> Daszak P, Scott DE, Kilpatrick AM, Faggioni C, Gibbons JW, Porter D (2005) Amphibian population declines at savannah river site are linked to climate, not chytridiomycosis. Ecology 86:3232-3237

Fahrig L, Pedlar JH, Pope SE, Tayler PD, Wegner JF (1995) Effect of road traffic on amphibian density. Biol Conserv 73:177-182

Farrer RA, Weinert LA, Bielby J, Garner TWJ and others (2011) Multiple emergences of genetically diverse amphibian-infecting chytrids include a globalized hypervirulent recombinant lineage. Proc Natl Acad Sci USA 108:18732-18736

Federici S, Clemenzi S, Favelli M, Tessa G, Andreone F, Casiraghi M, Crottini A (2008) Identification of the pathogen Batrachochytrium dendrobatidis in amphibian populations of a plain area in the Northwest of Italy. Herpetol Notes 1:33-37

Fisher MC, Garner TWJ, Walker SF (2009) Global emergence of Batrachochytrium dendrobatidis and amphibian chytridiomycosis in space, time, and host. Annu Rev Microbiol 63:291-310

> Garland S, Baker A, Phillott AD, Skerratt LF (2010) BSA reduces inhibition in a TaqMan ${ }^{\circledR}$ assay for the detection of Batrachochytrium dendrobatidis. Dis Aquat Org 92: 113-116

> Garner TWJ, Walker S, Bosch J, Hyatt AD, Cunningham AA, Fisher MC (2005) Chytrid fungus in Europe. Emerg Infect Dis 11:1639-1641

Greulich K, Schneeweiß N (1996) Hydrochemische Untersuchungen an sanierten Kleingewässern einer Agrarlandschaft (Barnim, Brandenburg) unter besonderer Berücksichtigung der Amphibienfauna. Naturschutz u Landschaftspflege in Brandenburg, Sonderheft Sölle 1996:22-30

> Hyatt AD, Boyle DG, Olsen V, Boyle DB and others (2007) Diagnostic assays and sampling protocols for the detection of Batrachochytrium dendrobatidis. Dis Aquat Org 73:175-192

- Khot PD, Fredricks DN (2009) PCR-based diagnosis of human fungal infections. Expert Rev Anti Infect Ther 7: 1201-1221

> Kinney VC, Heemeyer JL, Pessier AP, Lannoo MJ (2011) Seasonal pattern of Batrachochytrium dendrobatidis infection and mortality in Lithobates areolatus: affirmation of Vredenburg's '10,000 zoospore rule'. PLoS ONE 6:e16708

> Kirshtein JD, Anderson CW, Wood JS, Longcore JE, Voytek MA (2007) Quantitative PCR detection of Batrachochytrium dendrobatidis DNA from sediments and water. Dis Aquat Org 77:11-15

Klafs G, Jeschke L, Schmidt H (1973) Genese und Systematik wasserführender Ackerhohlformen in den Nordbezirken der DDR. Arch Naturschutz und Landschaftsforschung 13:287-302

Kriger KM, Hero JM (2007) Large-scale seasonal variation in the prevalence and severity of chytridiomycosis. J Zool Lond 271:352-359

Kulldorff M (1997) A spatial scan statistic. Commun Stat Theory Methods 26:1481-1496 
Kulldorff M (1999) An isotonic spatial scan statistic for geographical disease surveillance. J Natl Inst Public Health 48:94-101

Kulldorff M, Nagarwalla N (1995) Spatial disease clusters: detection and inference. Stat Med 14:799-810

Lam BA, Walke JB, Vredenburg VT, Harris RN (2010) Proportion of individuals with anti-Batrachochytrium dendrobatidis skin bacteria is associated with population persistence in the frog Rana muscosa. Biol Conserv 143:529-531

Lamirande EW, Nichols DK (2002) Effects of host age on susceptibility to cutaneous chytridiomycosis in blue-andyellow poison dart frogs (Dendrobates tinctorius). In: McKinnell RG, Carlson DL (eds) Proc Sixth Int Symp on the Pathology of Reptiles and Amphibians. Saint Paul, MN, p 3-13

Laufer H, Fritz K, Sowig P (2007) Die Amphibien und Reptilien Baden-Württembergs. Ulmer, Stuttgart

Lötters S, Kielgast J, Sztatecsny M, Wagner N and others (2012) Absence of infection with the amphibian chytrid fungus in the terrestrial Alpine salamander, Salamandra atra LAURENTI, 1768. Salamandra (Frankf) 48:58-62

Mendelson JR III, Lips KR, Gagliardo RW, Rabb GB and others (2006) Confronting amphibian declines and extinctions. Science 313:48

> Murray KA, Skerratt LF, Speare R, McCallum HI (2009) Impact and dynamics of disease in species threatened by the amphibian chytrid fungus, Batrachochytrium dendrobatidis. Conserv Biol 23:1242-1252

Mutschmann F (2007) Chytridiomycosis in Germany: an overview. In: Seybold J, Mutschmann F (eds) Proc 7th Int Symp on Pathology and Medicine in Reptiles and Amphibians, Berlin 2004. Edition Chimaira, Frankfurt, p 130-133

Mutschmann F, Berger L, Zwart P, Gaedicke C (2000) Chytridiomykose bei Amphibien: erstmaliger Nachweis für Europa. Berl Munch Tierarztl Wochenschr 113:380-383

Ohst T (2008) Genetische Einflüsse allochthoner Wasserfrösche auf endemische Wasserfroschpopulationen $(R . \mathrm{kl}$. esculenta komplex). PhD thesis, Humboldt-Universität, Berlin

Ohst T, Gräser Y, Mutschmann F, Plötner J (2011) Neue Erkenntnisse zur Gefährdung Europäischer Amphibien durch den Hautpilz Batrachochytrium dendrobatidis. Z Feldherpetol 18:1-17

> Ortiz-Santaliestra ME, Fisher MC, Fernández-Beaskoetxea S, Fernández-Benéitez MJ, Bosch J (2011) Ambient ultraviolet $\mathrm{B}$ radiation and prevalence of infection by Batrachochytrium dendrobatidis in two amphibian species. Conserv Biol 25:975-982

Phillott AD, Grogan LF, Cashins SD, McDonalds KR, Berger L, Skerratt LF (2013) Chytridiomycosis and seasonal mortality of tropical stream-associated frogs 15 years after introduction of Batrachochytrium dendrobatidis. Conserv Biol 27:1058-1068

Piovia-Scott J, Pope KL, Lawler SP, Cole EM, Foley JE (2011) Factors related to the distribution and prevalence of the fungal pathogen Batrachochytrium dendrobatidis in Rana cascade and other amphibians in the Klamath Mountains. Biol Conserv 144:2913-2921

Plötner J (2005) Die westpaläarktischen Wasserfrösche. Laurenti, Bielefeld

Plötner J, Matschke J (2012) Akut-toxische, subletale und indirekte Wirkungen von Glyphosat und glyphosathaltigen Herbiziden auf Amphibien: eine Übersicht. Z Feldherpetol 19:1-20
Rachowicz LJ, Knapp RA, Morgan JAT, Stice MJ, Vredenburg VT, Parker JM, Briggs CJ (2006) Emerging infectious disease as a proximate cause of amphibian mass mortality. Ecology 87:1671-1683

$>$ Raffel TR, Rohr JR, Kiesecker JM, Hudson PJ (2006) Negative effects of changing temperature on amphibian immunity under field conditions. Funct Ecol 20:819-828

Retallick RWR, McCallum H, Speare R (2004) Endemic infection of the amphibian chytrid fungus in a frog community post-decline. PLoS Biol 2:e351

Rödder D, Kielgast J, Lötters S (2010) Future potential distribution of the emerging amphibian chytrid fungus under anthropogenic climate change. Dis Aquat Org 92:201-207

Ron SR (2005) Predicting the distribution of the amphibian pathogen Batrachochytrium dendrobatidis in the New World. Biotropica 37:209-221

> Rosenblum EB, James TY, Zamudio KR, Poorten TJ and others (2013) Complex history of the amphibian-killing chytrid fungus revealed with genome resequencing data. Proc Natl Acad Sci USA 110:9385-9390

Schloegel LM, Hero JM, Berger L, Speare R, McDonald K, Daszak P (2006) The decline of the sharp-snouted day frog (Taudactylus acutirostris): The first documented case of extinction by infection in a free-ranging wildlife species? EcoHealth 3:35-40

Schmidt BR, Furrer S, Kwet A, Lötters S and others (2009) Desinfektion als Maßnahme gegen die Verbreitung von Krankheitserregern von Amphibien. In: Hachtel M, Schlüpmann M, Thiesmeier B, Weddeling K (eds) Methoden der Feldherpetologie. Z Feldherpetol (Suppl 15) Laurenti, Bielefeld, p 229-241

Schmidt C, Köhler J, Alfermann D (2011) Gefährdet Batrachochytrium dendrobatidis Amphibienpopulationen in Südhessen? Elaphe 19:33-37

Skerratt LF, Berger L, Speare R, Cashins S and others (2007) Spread of chytridiomycosis has caused rapid global decline and extinction of frogs. EcoHealth 4:125-134

> Skerratt LF, Berger L, Hines HB, McDonald KR, Mendez D, Speare R (2008) Survey protocol for detecting chytridiomycosis in all Australian frog populations. Dis Aquat Org 80:85-94

Skerratt LF, McDonald KR, Hines HB, Berger L and others (2010) Application of the survey protocol for chytridiomycosis to Queensland, Australia. Dis Aquat Org 92: 117-129

> Skerratt LF, Mendez D, McDonald KR, Garland S, Livingstone J, Berger L, Speare R (2011) Validation of diagnostic tests in wildlife: the case of chytridiomycosis in wild amphibians. J Herpetol 45:444-450

Stangier U (1988) Kleingewässerrückgang im westlichen Münsterland und heutige potentielle Vernetzung der Amphibienpopulationen. Jb Feldherp (Beih 1): $117-127$

Sztatecsny M, Glaser F (2011) From the eastern lowlands to the western mountains: first recordings of the chytrid fungus Batrachochytrium dendrobatidis in wild amphibian populations from Austria. Herpetol J 21:87-90

Sztatecsny M, Hödl W (2011) Chytridiomycose in Österreich: Bestandsaufnahme einer tödlichen Amphibienkrankheit. Projekt 100445 der Bund/Bundesländer-Kooperation. Endbericht März 2011. Department für Entwicklungsbiologie, Universität Wien

Tobler U, Schmidt BR (2010) Within- and among-population variation in chytridiomycosis-induced mortality in the toad Alytes obstetricans. PLoS ONE 5:e10927 
Voordouw MJ, Adama D, Houston B, Govindarajulu P, Robinson J (2010) Prevalence of the pathogenic chytrid fungus, Batrachochytrium dendrobatidis, in an endangered population of northern leopard frogs, Rana pipiens. BMC Ecol 10:6

Vredenburg VT, Knapp RA, Tunstall TS, Briggs CJ (2010) Dynamics of an emerging disease drive large-scale amphibian population extinctions. Proc Natl Acad Sci USA 107:9689-9694

Waldman B, van de Wolfshaar KE, Klena JD, Andjic V, Bishop PJ, de Norman RJ (2001) Chytridiomycosis in

Editorial responsibility: Lee Skerratt,

Townsville, Queensland, Australia
New Zealand frogs. Surveillance 28:9-11

Walker SF, Bosch J, Gomez V, Garner TWJ and others (2010) Factors driving pathogenicity vs. prevalence of amphibian panzootic chytridiomycosis in Iberia. Ecol Lett 13: 372-382

Wegener U (1983) Gestaltung wassergefüllter Sölle in der Agrarlandschaft. Arch Naturschutz und Landschaftsforschung 23:151-163

Woodhams DC, Alford RA, Marantelli G (2003) Emerging disease of amphibians cured by elevated body temperature. Dis Aquat Org 55:65-67

Submitted: January 7, 2013; Accepted: August 26, 2013

Proofs received from author(s): November 5, 2013 